Society lifts publishing ban on nations facing

\section{US sanctions}

Washington The American Chemical Society has announced that it is lifting a moratorium on the publication of scientific manuscripts from Iran, Libya, Sudan and Cuba.

The decision on 19 February came a week after a meeting with US government officials, who warned that accepting manuscripts from the four countries falls foul of current embargoes (see Nature 427, $663 ; 2004)$. Robert Bovenschulte, who heads the society's publications division, says the group decided to lift the moratorium, which has been in place since November, after reviewing trade and constitutional law. "We believe it's the right thing to do," he says.

Bovenschulte says that several scientific publishers are working with the White House and Congress to reverse the government ruling, which they believe violates the US First Amendment invoking the right to free speech. He also says that the society is considering legal action, but only as a last resort.

"I think Iranian chemists will be happy to see that these restrictions have been removed," says Habib Bagheri, a chemist from the Sharif University of Technology in Tehran, Iran, who is currently a visiting scholar at Purdue University in Indiana.

\section{Gamers promise army the} world for virtual training Washington The US army has teamed up with a computer games company to create a simulation of the whole Earth.

In a bid to help soldiers train around the globe without travelling, army researchers are working with There, a company based in Menlo Park, California, that specializes in games set in realistic three-dimensional environments. Together they will build a

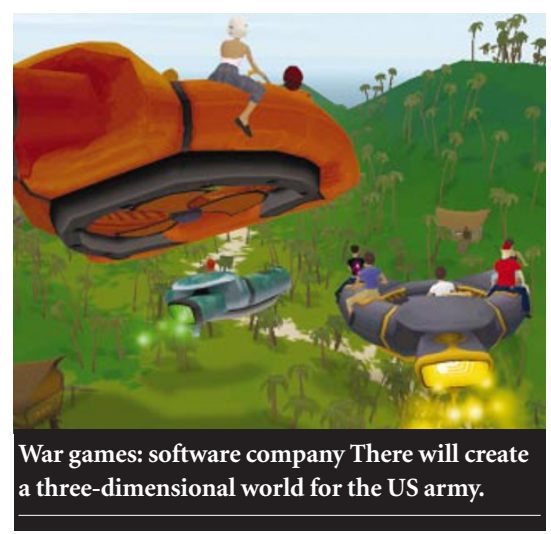

virtual model of the entire planet, using existing data about Earth's terrain. Robert Gehorsam, a senior vice-president at There, says that the product will model the real world as closely as possible.

The artificial world will help the army to practise intelligence work, patrols and planning, as well as encounters with civilians. A group of soldiers who served in Iraq will test the system in the spring; a final version is hoped to be in place by September. But the team has a long way to go - so far only part of Kuwait City has been modelled in detail.

\section{Human pesticide tests 'given green light'}

Washington A National Academy of Sciences panel has advised the US Environmental Protection Agency to accept data from pesticide companies that test their products on humans - but only when the tests have been conducted under strict ethical guidelines.

Some chemical manufacturers, claiming that dosage limits extrapolated from animal tests are too stringent, have submitted human test data when seeking approval for pesticides. But when the Environmental Protection Agency's science advisory committees couldn't decide on the issue, the agency asked the academy to look into 
it and stopped accepting human test data. That suspension was overruled by a US appeals court in June.

The academy panel also advised that human tests should not be done simply to establish a lower acceptable dose under agency regulations without offering a public-health benefit.

But Richard Wiles, senior vice-president of the Washington-based Environmental Working Group, says: "The chemical industry will view the report as a green light to continue the highly unethical practice of dosing people with pesticides."

\section{Drug trial in monkeys offers hope of SARS treatment}

London A drug used to treat hepatitis $\mathrm{C}$ has been shown to relieve the symptoms of severe acute respiratory syndrome (SARS) and reduce infectiousness in monkeys.

In a study published this week in Nature Medicine, a team led by Albert Osterhaus of the Erasmus Medical Centre in Rotterdam, the Netherlands, tested the antiviral drug interferon- $\alpha$ on macaques.

Monkeys were given doses of the drug and then infected with SARS. Two days later, their throats were almost free of viral particles, meaning that they exhaled fewer infectious particles - unlike untreated animals. "If the same thing is seen in human patients, maybe the virus will spread less," says Osterhaus.

The next step is to test the drug against SARS in humans, if another outbreak occurs.

\section{Plague vaccine shows early promise}

London British scientists are claiming early progress in developing a candidate vaccine against the bacterium that causes plague.

The scientists, led by Rick Titball, a microbiologist at the UK Ministry of Defence's laboratory in Porton Down, say their vaccine is based on proteins from the bacterium, Yersinia pestis, that activate the human immune system without causing

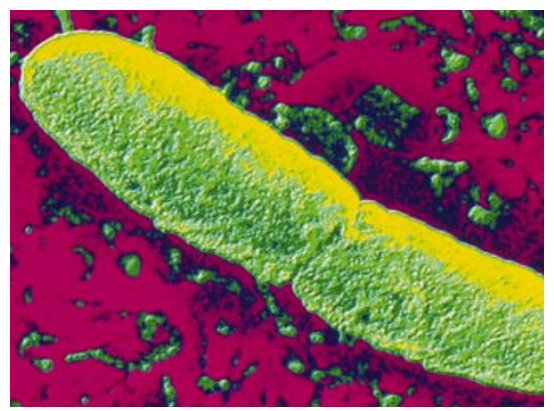

The plague bacterium Yersinia pestis could form the basis of a bioterror threat. disease. Titball tested the vaccine on a small group of healthy volunteers and found it to be safe. His team now wants to conduct a large-scale efficacy trial involving several thousand volunteers.

There is currently no effective vaccine against plague, which could theoretically be used in a bioterrorist attack.

\section{HIV enzyme boosts base} amplification of artificial DNA London Researchers led by Steven Benner of the University of Florida have designed an enzyme that allows non-natural DNA to replicate itself (A. M. Sismour et al. Nucl. Acids Res. 32, 728-735; 2004). The enzyme multiplies DNA that contains extra 'letters', or bases, beyond the naturally occurring cytosine, guanine, thymine and adenine. DNA with artificial bases has been around for several years but the strands could not reproduce themselves automatically.

The new enzyme, based on a polymerase produced by HIV, can string together DNA strands containing six nucleotide letters, rather than the usual four. DNA probes containing artificial bases are often used to detect viruses such as hepatitis $\mathrm{C}$, and this discovery could radically speed up the production of these probes, Benner suggests. 